\title{
Doing the Right Thing Right: The Role of Sociological Research and Consulting for Corporate Engagement in Development Cooperation
}

\author{
Claus-Heinrich Daub \\ Yvonne M. Scherrer
}

\begin{abstract}
The purpose of this article is to illustrate the role of sociology in the field of corporate social responsibility (CSR). It presents a case study conducted by a research group consisting of two University partners in association with a Swiss SME. This project attempted to draw conclusions from a specific sociological consultancy research project on the general possibilities and opportunities of sociology in applied research and operational sustainability consulting. On the basis of the project findings, the article reflects on the extent to which sociology could profitably intervene, on the limitations for sociological research and consultations in this field and on the conclusions that can be drawn for future analyses.
\end{abstract}

KEY WORDS: applied sociological research, corporate social engagement, corporate social responsibility, sociological consulting, sustainable, management

Claus-Heinrich Daub is Director of the Center of Sustainable Management at the University of Applied Sciences Northwestern Switzerland. He heads the International Network for Sustainable Management (IfSM) and is the current President of the Society for Scientific Publishing in Switzerland. Previous publications include contributions to sustainable management, economic sociology and strategic marketing and communication.

Yvonne M. Scherrer is Project Manager in sustainability-related research projects at the University of Applied Sciences Northwestern Switzerland, School of Business, and organiser of the 1st and 2nd International Sustainability Conferences ISC 2005 \& ISC 2008 in Basel. Her current research activities focus on stakeholder interactions in the context of (natural) resource management. She is a PhD student at the University of Basel and currently vice-president of the Society for Scientific Publishing in Switzerland.
During the discourse on sustainable development and the contributions to be made by various social organisations, demands on companies to show more responsibility for their social and ecological environment have increased markedly in recent years (Daub, 2005). After a certain delay, this also led to a growth in theoretical and practical concepts known by various names. Of these, the term 'corporate social responsibility' (CSR) has undoubtedly assumed the most prominent position since the publication of the European Commission Green Paper on the subject (Europäische Kommission, 2001). Corporate social responsibility is a "cluster concept which overlaps with such concepts as business ethics, corporate philanthropy, corporate citizenship, sustainability and environmental responsibility" (Matten and Moon, 2005, p. 335; cf. Hopkins, 2003, p. 9). At the core of the concept are the questions of how companies perceive their general responsibility to society and the specific concerns of their stakeholders and how they develop a management approach that attempts to reconcile their economic objectives with environmental and social concerns.

The literature on CSR gives different answers to these questions. Regarding the first one, the debate focuses on arguments of why companies should and must face their responsibility at all. The respective answers vary depending on whether they are given from a marketing or a sociological point of view. Marketing views the assumption of more responsibility primarily as a 'success factor' (Gazdar et al., 2006) and catalogues opportunities that arise from or can be enhanced by social engagement. In their latest publication on the subject, for example, 
Philip Kotler and Nancy Lee name the following six "bottom-line benefits": increased sales and market share, strengthened brand positioning, improved corporate image, increased ability to attract, motivate, and retain employees, decreased operating costs and increased appeal to investors (Kotler and Lee, 2005 , p. 10f). From the (economic) sociological point of view, however, CSR is an elementary part of ethical corporate reorientation in a time of environmental and social crisis (Hillmann, 1988, p. 261). The central idea here, then, is that for normative ethical reasons companies should and must make a contribution to sustainable development to boost this process (Daub, 2005, p. 19).

A second theme in the CSR discourse focuses on arguments to rationally underpin the 'how' of corporate social engagement, specifically the naming of objectives for an activity in the interests of an identifiable "value-adding contribution for society" (Habisch, 2006, p. 37), the specification of the scope of potential activities, the selection of the object or subject of any financial or nonfinancial engagement, the identification of possible alliances with civil-society organisations, and the measurement of success by determining the positive (and possibly negative) impact of the activities. Elsewhere we have, for example, argued for a management approach, which systematically draws on insights derived from the political discourse on sustainable development and strives for a harmonisation of economic, environmental and social aspects of corporate management, and termed it "sustainable management" (Daub and Ergenzinger, 2005, p. 1001). Generally speaking, this 'business case' has become an area of intensive investigation in management theory and marketing and a number of independent approaches to success enhancement have already been developed from it (Grayson and Hodges, 2004). Sociology, however, has so far only very marginally contributed to the advancement of understanding the 'how'.

We take that to be a disadvantage not only for sociology itself, but also for CSR in general. According to what we already said, each operationalisation of the CSR concept faces normative questions and calls for adequate knowledge concerning the social and ecological environment of the business in question. One is only able to deduce promising options for activities from a CSR concept if both elements are rationally linked together. In view of these tasks, one even expects sociology to intuitively contribute to it, given that sociology is of course methodically well equipped to analyse such topics. Hence, the first question to be asked is why these expectations have so far not been satisfied. The second question then will be in what respect we are able to give these expectations a sound basis.

There are several reasons sustaining sociology's absence in that respect. On the one hand, this may be related to its traditional scepticism towards corporate social engagement, whose intentions are still assumed to be 'insincere' because they focus primarily on corporate business success and only secondarily on the improvement of social conditions. This is clearly demonstrated by the current criticism of publicprivate partnerships (PPPs). One current study, for example, shows that PPP projects are largely conducted in emerging nations such as China, Brazil and South Africa which are commercially attractive to the companies involved, whereas poorer countries are ignored; the development-related benefits of PPPs are too limited, it is argued, although their investment and business promotion character is markedly distinct (Hoering 2003, p. 27ff).

On the other hand, the aforementioned scepticism is to be found in sociology's continuing lack of application orientation (Bommes et al., 1991, p. 95; cf. the discourse in Beck and Bonss, 1989). In the German-speaking countries, at least, the term 'applied sociology' is frequently associated with 'social work', something that does justice to neither discipline. Tied to this erroneous perception is the general conviction that sociology should allow itself to be instrumentalised in the interests of an application orientation only, and at most, if the aspired to result can at least be considered a positive intervention in the social realm - i.e. if it contributes to the resolution of social problems such as crime, drug abuse or prostitution, for example.

Accordingly, placing oneself at the service of business - even if only temporarily - to help it solve its problems and issues is not viewed as a task of sociology. Even the more recent studies on economic sociology make no mention of any function of this subdiscipline other than the analysis of economic action, market processes and the relevant key 
norms and institutions (cf. Hirsch-Kreinsen, 2005, p. 11; Smelser and Swedberg, 1994, p. 3ff). Even industrial sociology maintains a critical distance to avoid exposing itself to the suspicion that "the science might become an affirmatively acting enforcement body for interests that themselves should be the subject of scientific investigation" (Bollinger and Weltz, 1989, p. 249).

Even if this scepticism seems understandable in part, the reservation, or even ignorance is opposed to the expectations sketched above. Moreover, it is regrettable for a number of reasons. Above all it contributes to a situation in which companies too often base their CSR activities on purely business considerations, losing sight of their intrinsically superordinate ethical foundation and their social integration functions in the process (Daub, 2004, p. 153ff). This underlying problem finds excellent expression in the idea of a 'corporate-citizenship mix' recently introduced into the scientific discourse (Dresewski, 2004, p. 21f). For when companies consider their society-oriented activities solely from a marketing perspective, they will always control and combine them in a manner that ultimately yields the highest benefit for the company's operating profits. In practice this means that the persons, groups or actions supported will mainly be those that offer an opportunity to "earn some money". This phenomenon is already sufficiently known from the field of sponsorship, for example, where much more money flows into sport than does into social projects, as companies expect to obtain more positive image effects and opportunities to link in with their advertising strategies from the former than the latter.

Therefore, what can be the role of sociology in the field of CSR? We see three prime areas of activity:

1. The task of basic sociological research should be to "underpin the social dimension of corporate sustainability in a conceptual respect" (Becke, 2003, p. 537). It could thus make a contribution to a discourse that has been increasingly taking place in the field of business administration and in business circles in and beyond Switzerland for some time now (cf. ÖBU/TSF/zsa-ZHW, 2005), though no social scientific contributions have been identified to date.
2. The prime function of applied sociological research in the aforementioned context is to identify, analyse and describe social problem areas in which corporate engagement can yield as far-reaching a positive impact as possible. The aim would be to present companies with options for activities in a social problem area and highlight the potential 'pitfalls' of any engagement.

3. Sociological consulting, as 'exotic' as the term may continue to appear in view of the rarity of the process it describes (cf. Bollinger and Weltz, 1989, p. 250), could concern itself with initiating and mentoring learning processes for sustainable corporate management in organisations, mentoring the resulting organisational change while ensuring the social dimension of sustainability is implemented in the company's integrated sustainability strategy, and finally advising the company on the implementation of specific individual measures.

If we wish at all to speak of sociology having addressed the subject of sustainability in general and operational sustainability in particular to any noteworthy extent, we can do so in the first area. The other two, however, are 'poor cousins' for the aforementioned reasons. This observation was also the starting point for a project conducted by a research group from the Institute of Sociology at the University of Basel and the Center of Sustainable Management at the University of Applied Sciences Northwestern Switzerland in association with the company Knecht \& Müller AG.

The text below looks at this project, in which an attempt was made to draw conclusions on the general possibilities of sociology in the field of applied research and operational sustainability consulting from a specific sociological consultancy research project. It begins by describing the situation that yielded the project application and the principal research question before outlining the methodological approach and the project results. Finally, on the basis of our findings we reflect on the extent to which sociology could profitably intervene here, the limitations for sociological research and consulting in this field and the conclusions that can be drawn for future analyses. 


\section{The starting point: the good will to engage}

With an annual production of approx. 250,000 spectacle lenses and about 50 employees, Knecht \& Müller AG of Stein am Rhein is one of the leading manufacturers of prescription lenses in Switzerland. In the mid-1990s, the company began to systematically gear itself towards sustainable management. This found its first public expression in the publication of an environment report in 1997, which was superseded by a second environment report in 2000 and finally by the company's first sustainability report in 2002. The company was thus one of the first in Switzerland to present a sustainability report in the narrower sense containing details on the company's economic, environmental and social performance in a given period (Daub et al., 2003, p. 27). Two years later a second sustainability report was ranked the eleventh best in Switzerland, placing it ahead of all other small- and mediumsized enterprises (Daub et al., 2005, p. 42). Along with the 2003/2004 Annual Report on the Sustainable Development of Knecht \& Müller AG the company published a brochure outlining its most important maxims for action. In it the company defines its visions as follows: "For us sustainable development means basing ourselves on the needs of people rather than a short-term profit mindset. It is not just about environment protection or the careful use of resources. We show consideration for our surroundings and the people we deal with in everything we do" (Knecht and Müller AG, 2005, p. 9).

This corporate philosophy later spawned the idea of a long-term social engagement in an as yet unspecified area of society. Initially the term 'engagement' was deliberately left open and embraced a spectrum from the concept design and implementation of a fully independent company (aid) project to the provision of financial, material and/or nonmaterial support to an existing aid organisation project or programme or a purely financial engagement in the form of a simple donation.

As the company management realised from the outset that their planned social engagement would take them into an area where they lacked the necessary expertise, they began by searching for strategic alliance partners and found them in the authors of this article, with whom they laid down the framework of the intended engagement and the process that was to lead to a specific activity. Here, the project team based itself on findings from sociological consulting with respect to the sustainable development of organisations (Becke, 2003, p. 535) and on guidelines for the identification and management of specific projects under a superordinate CSR or corporate-citizenship strategy (Behrent and Wieland, 2003; Dresewski 2004; Habisch 2006; Kotler and Lee 2005).

The negotiations yielded the following requirements for the planned engagement activity:

1. A central requirement on the engagement activity to be developed during the course of the project was its pilot character: The company wanted the process of developing the engagement activity to be seen as a transdisciplinary learning process in which knowledge resources were to be produced in association with an external partner. Directly linked to this was the requirement that the project should not be too complex.

2. An additional consideration that was closely linked to the first requirement related to the promotional character of the process: The applied research process itself was to be seen as a social engagement activity by the company that would have a positive impact even if the results of the analysis of the as yet unspecified area of action showed that no engagement activity with sufficient value-added was feasible.

3. The aspired to innovative and exemplary character was to influence the project in two respects: first in adopting an innovative approach when developing the 'end product' and second in demonstrating that small businesses are more than capable of making a contribution to sustainable development.

4. Less importance was deliberately attached to the project's innovative economic character and business-case character although the engagement activity was to demonstrate a relationship with the business of Knecht \& Müller AG.

Based on these requirements two options were ruled out from the outset. The first was any engagement activity by the company within a 
public-private partnership, a concept that is still very new in Switzerland (for the status of the discussion in Switzerland see Younossian and Dommen, 2005) and which the Swiss Agency for Development and Cooperation (SDC) and the State Secretariat for Economic Affairs (SECO) have only just begun to develop systematically (Chassot Gétaz et al., 2005). The relationship between cost and the potential 'social' return was impossible to predict, which made such an engagement activity appear too fraught with risk. Second, the aspired to promotional character of the project ruled out the involvement of a 'classical' consultant.

Ultimately, the team decided to select a development-related problem and have it analysed by a group of social-science students at the University of Basel. This had two objectives: The students were to be given an opportunity to acquaint themselves with empirical social research methods and learn to apply them while working in a group, while the company was to be provided with an overview of the actors, their experiences and the existing alliances and projects in the development-related problem area, allowing it to define a specific engagement activity on this basis.

Vision correction for people without the material means to obtain it was selected as the problem area in which a social engagement activity by the company was considered expedient and feasible in principle. The (medium-term) objective of any potential engagement was that it should render a positive contribution to development cooperation in such a way that as many vision-impaired people as possible who cannot afford vision correction would be provided with optimum help as a result of the activity.

This choice of problem area guaranteed a direct relationship with the business of Knecht \& Müller AG. Regardless of the specific engagement activity yielded by the evaluation phase, the ability of the company to make a positive social impact in this area was thus given. Moreover, as it was an issue that is not a 'core area' of development cooperation such as the fight against poverty, hunger or epidemics, the problem area appeared sufficiently innovative. And finally, following an initial rough analysis it was to be assumed that the company's engagement could create sufficient public impact and that any potential project would therefore fulfil an exemplary function.

\section{From good will to clarifying the field}

\author{
Background: eye disease and vision impairment \\ in developing nations
}

According to Vision 2020, a global campaign to eliminate the main causes of blindness, an estimated 180 million people worldwide were affected by eye diseases of all kinds in the year 2000 (www.vision2020.org, accessed August 14, 2006). The majority, around 135 million, suffer from some degree of vision impairment, while some 45 million are blind. The number of blind people has risen continuously over the last 25 years from 30 to 45 million and 1-2 million people lose their sight every year. Projections of the expected global development have revealed that without more widespread initiatives the number of blind people will have risen to about 75 million by 2020 . Some $60 \%$ of blindness can be attributed to refractive errors and cataracts, which for reasons as yet unknown occur much more often and on average 10-15 years earlier in developing nations than in industrial nations and could be remedied by relatively simple surgery. Some $15 \%$ of blindness is caused by trachoma, vitamin A deficiency or as a direct result of onchocerciasis (river blindness); all of these diseases are avoidable. A further 15\% of blindness is related to diabetic retinopathy or glaucoma; in both these cases treatment proves more problematic. The same applies to the remaining 10\% of blindness that is attributable to macular degeneration and other diseases and whose treatment continues to be the subject of research. Listing the four primary causes highlights two things. On the one hand, some $60 \%$ of blindness could be treated with the appropriate medical care and at least 15\% could be prevented by relatively easy means. On the other hand, the clinical picture clearly shows that developing nations are affected much more significantly by the blindness problem. In fact, some $90 \%$ of blind people live in developing countries, where they are unable to provide for themselves and thus become a burden on their families, frequently experiencing social exclusion in addition to their physical disability. 
Concept, progression and results of the empirical investigations

The research study began with the students being given a detailed introduction to the problems of development cooperation at the root of the research area and the subject of CSR. They were also introduced to qualitative social research techniques on the basis of relevant literature (Helfferich, 2005; Lamnek, 2005), especially the theory and practice of the expert interview (Gläser and Laudel, 2004; Meuser and Nagel, 2005).

In-depth research was then conducted, primarily on the internet, to obtain an initial overview of the 'eye disease and vision impairment' problem and the development actors involved. This introductory analysis yielded the following four central observations:

1. The primary activity of organisations involved in rectifying vision impairments (not eye diseases) seems to be the collection of old spectacles deposited by their previous owners at special collection points - usually opticians' practices - or collected by the organisations as part of a campaign.

2. In the context of the activities of national state institutions involved in development cooperation (in Switzerland especially the aforementioned SDC), vision impairment appears to play a marginal role.

3. There appears to be few corporate activities in this field, among them individual financial donations, staff deployments and the provision of materials required by aid projects. Depending on the company making the donation, materials comprise medical devices, tools, walking sticks and eye test posters, etc. or, as in the case of the spectacle lens manufacturer Knecht \& Müller AG, lenses and frames. The materials donated are used by aid projects in the areas of prevention, cure and rehabilitation. Spectacle lenses and frames such as those made by Knecht \& Müller AG are generally used either to prevent a further deterioration in eyesight or to relieve the eyes in the rehabilitation phase following surgery.

4. Overall very little information and data are available in the field.
Based on these observations, the research team created the following six projects to allow the problem to be examined from as many different perspectives as possible. In view of the situation described the projects focused primarily on vision impairment and correction, as the client was very likely to continue engaging in this field. A detailed research plan ensured that the projects were well coordinated in terms of content and time and there would be no unnecessary duplication - e.g. as a result of two groups contacting the same expert.

1. The first project concerned itself with the development cooperation organisations in Switzerland that are active in the area of vision correction devices. These organisations were investigated as to how and why they engage in the area under discussion and how they network with each other.

2. A second group analysed two specific private aid projects that are active in the area of vision correction devices in Switzerland and Germany. These specific case studies were designed to paint an extensive picture of the experience gained by the project initiators and ascertain their original motivation.

3. The subject of cultural/social acceptance was examined in the third project, which concerned itself explicitly with the local impact of aid projects in the 'vision' area. Expert interviews were used to ascertain what impact 'spectacle donations' have on the local economy and society in the donee countries and how this impact is evaluated.

4. The fourth project looked at actual and potential 'suppliers' of donated materials, i.e. second-hand spectacles from the Basel region. In Basel city centre passers-by were asked how many unused pairs of glasses they had at home, what they knew about the collection points for unwanted spectacles and whether they were generally willing to donate their unused spectacles.

5. The fifth research group focused on the activities of small and medium-sized enterprises in the area of vision correction devices. They interviewed ophthalmologists, opticians and representatives of the relevant associations in 
northwest Switzerland on their engagement activities in the area of development cooperation and their network structure.

6. Building on this, the sixth project looked at the associated activities of large companies whose product portfolios exhibit a relation to vision correction devices. The companies involved were chains of opticians, spectacle and lens manufacturers and makers of opticians' equipment and accessories. The interviews focused on the various models of cooperation with development agencies, the control and evaluation of activities in developing countries and the companies' communications strategies with respect to their development-related engagement activities.

Focusing on the specific findings from the empirical investigations, the results of the six aforementioned projects are presented below.

The first project concerned itself with the development cooperation organisations in Switzerland that are active in the field of vision correction devices. It emerged that the field was primarily covered by smaller, less well-known development agencies and was generally integrated in the wider field of blindness prevention/eye diseases. In most cases the collection, cleaning, sizing, marking and distribution of (second-hand) spectacles constituted just a (small) part of the overall project. Some of the development agencies fall back on second-hand spectacles collected in Switzerland and Europe, whereas others purchase some of their spectacles, or at least the lenses, in India, China and Southeast Asia. The reasons given were low local production costs, the creation of local jobs and the high shipment costs from Europe. Some development agencies dispense the finished spectacles for free, whereas others levy a small charge according to the recipient. How this functions in practice is heavily dependent on the local income structure. In general the development agencies provide medical equipment as well as spectacles, initiate the establishment of eye clinics and optician centres and launch blindness prevention programmes and education campaigns, working closely with local partners. In the interests of sustainable development aid, they usually train local staff to allow the project activities to be handed over to them in the long term. The situation as regards the networking of the development agencies in Switzerland is rather contradictory. While the organisations are generally relatively well networked in their target countries, the willingness to cooperate in the country of origin appears to be less well pronounced. Certain organisations, for example, have enough or even too many donated spectacles and are not accepting any more at the moment, whereas other actors report a lack of spectacles and other vision correction devices. In general, however, all development agencies still have a demand (at least) for children's, reading and sunglasses, which are more difficult to obtain.

The research group that examined two private aid projects in the area of 'eye diseases/vision correction devices', i.e. the 'Hans Haller Foundation' in Switzerland and a blindness elimination campaign ['Blindenheilung Bangladesh'] run in Bangladesh by the German-based aid organisation 'Andheri Hilfe', revealed a number of interesting findings. Their analyses confirmed the observations made by the first research group that most of the organisations in the German-speaking region not only specialise in the distribution of spectacles or other vision correction devices, but also operate in cure, prevention and rehabilitation in the area of 'eye diseases'. The 'Blindenheilung Bangladesh' campaign, for example, has established eight eye clinics that also serve as training and further education centres, invested in the training of teachers in the area of health education and vision impairment and, in 2004, launched a number of mobile 'eye camps', which perform eye examinations and surgery in remote areas and offer help and advice in the area of hygiene and diet. A different approach has been adopted by the 'Hans Haller Foundation', which according to its own communications places its faith in diversification, distributes hearing aids as well as spectacles, and works in family planning, children's aid, vocational training and water treatment. While the distribution of spectacles, with which the foundation commenced its activities in 1995, has since been relegated to a more secondary role, it served as an important door opener to government bodies for its other aforementioned activities, as it provided a clear signal that the foundation was not merely demanding something from these bodies, but was also prepared to contribute.

The original motivation for both organisations to get involved in the area of vision correction devices 
in a developing nation was based on the personal affiliation and concern of the initiators with the relevant country or region. As far as the actual materials are concerned - spectacles and vision correction devices of all types - the two organisations take different approaches according to the respective local situation. Although spectacle lenses are cheap in Brazil, the frames are much more expensive. The 'Hans Haller Foundation' therefore continues to accept spectacles and discontinued frames from opticians and private individuals and distributes them to the needy in Brazil through a partner NGO. In contrast, the 'Blindenheilung Bangladesh' campaign stopped shipping secondhand spectacles and other vision correction devices around two years ago because India has had a flourishing spectacles industry for some time. It therefore made no financial sense to check and dispatch materials from the West and also put local jobs at risk.

The cultural and social acceptance of vision correction donations was the subject considered by the third research group, which concerned itself explicitly with the economic and social impact of such aid projects. Interviews were conducted with six experts who are versed in the issue through their profession, be they representatives of an aid organisation, ophthalmologists or foreign correspondents in Africa. It was noticeable that with one exception all those questioned were of the opinion that the projects and activities under discussion generally had a positive regional impact, were roundly welcomed by the local population and made a decisive contribution to improving the respective situation. In addition to the improvement in ophthalmological care, the creation of local jobs and training of local staff were additional positive effects frequently mentioned, the latter embracing areas such as accounting, management and organisation as well as the actual medical specialisation. It was also emphasised that care was taken to ensure that aid really was appropriate at the corresponding location and did not pose a threat to local business. Competition with local vision correction offerings was not a concern, however, in the vast majority of cases. No opticians were based in the remote project locations and/or the target audience, most of whom lived below the poverty line, could not afford the offering in any case, which was aimed at richer sections of the population. In addition, the better-off preferred to buy their own choice of glasses from an optician, as spectacles were often seen as a status symbol, especially in Africa. Notwithstanding this generally positive assessment, reference was also made to the problems associated with project work. It was sometimes the case that governments withdrew from the corresponding health sector because of the projects, leaving the work to be done by the development agencies, a situation that could not be tolerated, however, as in the interests of sustainability local actors also needed to contribute to the projects. Only one person expressed concern about the supply of donated vision correction devices, saying that while it was positive in the short term, in the long term, however, it was problematic because of the resulting dependency on aid. Local production of vision correction devices could, however, counteract such a development.

The fourth research group investigated the subject of 'spectacles collection' by interviewing passers-by in Basel city centre on two separate occasions. As assumed above, it emerged that the number of unused spectacles is high. According to this (unrepresentative) survey an average household has 1.63 unused pairs of glasses. In contrast, relatively little is known about the collection points for unused spectacles. Some two-thirds of those questioned were unable to name a collection point. The remaining third named an optician's practice in 51\% of the cases and was also aware that the spectacles were usually distributed as development aid. Development agencies and aid organisations as direct takers of secondhand spectacles were named as possible collection points by $21 \%$. The question regarding the general willingness to donate unused spectacles had to be posed indirectly, as it was to be expected that a direct enquiry would meet with broad agreement, but would not explain the relatively large number of unused spectacles in Basel households. For this reason those questioned were asked why they thought many people held on to their unused spectacles. A total of $95 \%$ could think of one or more reasons. A lack of knowledge about donation options (23\%), the desire to keep a spare pair (19\%), emotional considerations $(11 \%)$ and laziness (10\%) were the reasons most frequently named.

The fifth project concentrated on the activities of small and medium-sized enterprises (SMEs) in the area of 'vision correction devices'. They interviewed 
ophthalmologists, opticians and the relevant associations on their engagement activities in the field of development cooperation, the motivation behind such activities and their networking contacts with other actors. It emerged that the associations did not organise or push the collection of second-hand spectacles themselves. While the Association of Swiss Opticians (SOV/ASO) provides its members with a list of addresses for the development agencies active in the area of 'vision correction devices', the individual opticians organise their relief activities independently. Some refer to the possibility of donating spectacles only in direct consultations with customers, whereas others publicise their engagement activities on their website or in their in-house magazine. In view of these organisational options and this voluntariness, the amount of material collected by opticians is astonishing. Accordingly, neither the opticians' practices and their associations nor the larger development agencies such as the 'Christian Blind Mission' (CBM) consider it necessary to drive their collection-activities forward by the use of targeted advertising. One exception to this, however, is in the collection of children's, reading and sunglasses and technical equipment. According to the research group's findings there are generally three types of aid activity to be identified. First there are the traditional collection-activities at optician's practices, with all of the practices affiliated to the Association of Swiss Opticians (SOV/ASO) accepting second-hand spectacles. Ultimately, however, only $30-50 \%$ of the spectacles collected can be passed on to development agencies. A second type of aid activity involves the collection of ophthalmological instruments that are still useable but no longer satisfy the technical requirements here. In the Basel area this is largely done by 'Opportunity Recycling in Ophthalmology' (ORO), a campaign run by the Basel Eye Clinic. Third, there is the deployment of staff. At large opticians' practices young trainees, in particular, travel out to aid projects to conduct eye tests and fit spectacles. Cooperation between the various actors takes on varied forms. Whereas opticians' practices and the 'Association of Basel Opticians' seldom receive specific enquiries from development agencies and usually have to establish contact themselves, the contact between development agencies and ophthalmologists and their associations is much more intensive, allegedly due to the greater deployability of doctors. Essentially, however, networks and alliances between interested actors often come about through personal contacts. This informality would, however, appear to involve a certain intransparency. It is often rather unclear which organisations are working together and not infrequently individual organisations will know their next point of contact, but not the entire field. In this respect, NGOs such as ORO sometimes provide important mediation between development agencies, opticians' practices, eye clinics and local initiatives in developing countries. Yet if these groups were to improve their cooperation, the activities could be coordinated better and costs reduced by obtaining more attractive prices for larger quantities.

The research group which looked at the activities of major companies in the area of "vision correction devices' contacted a selection of 20 firms in Switzerland, Germany, Austria, Italy and Sweden. Of the 13 companies who were ultimately willing to participate in the project, eight are involved in development cooperation. The models of cooperation between these companies and aid organisations and projects were extremely varied. Some companies support aid projects on request, for example. Longterm relationships are not always entered into, which means the aid organisations constantly have to submit new applications. One company has set up a fund for this purpose, for example, through which it sends development agencies intraocular lenses on request. Some companies seek longer-term partnerships during which they support the development agencies by regularly donating money, "vision correction devices' and medical instruments, sharing expertise and sending out experts. Some take the initiative and contact development agencies themselves, while others form alliances with other companies for the purpose of coordinating their activities or launch their own projects in developing countries. The companies also adopt different approaches when it comes to the evaluation of their engagement activities. Some send an employee to visit the project once a year, while others are happy simply to receive verbal feedback and/or photos from the corresponding development agency. Some companies seek to establish a relationship of trust with the partner organisation and conduct no inhouse evaluation, whereas for others a certain amount of quality control is given through the initial 
evaluation of the project applications submitted by the development agencies. Generally, however, few companies appear to analyse the specific local impact of the aid provided and tend to leave this area to the development organisations on the ground. It is noticeable that the engagement activities of the companies in the area of development cooperation are rarely reflected in their communication strategies. With two exceptions they do not usually publicise their activities on their websites, or if they do, then only implicitly. In addition, they sometimes seem rather unprepared for enquiries about their development engagement activities. There was a case, for example, where the responsible person was not known to the switchboard and could only be identified after the call had been forwarded several times, a circumstance that shows how difficult it can be for interested parties, especially development agencies, to obtain further information on the company's engagement activities.

\section{Findings on the role of applied sociological research and consulting}

Above, we outlined three task areas for sociology in the context of CSR and assigned them to the activity areas basic research, applied research and consulting. Serving as a pilot project, the aforementioned project was intended to help ascertain the role and usefulness of the second and third areas, i.e. applied sociological research and sociological consulting, on the basis of practical experience.

If we begin by examining the course of the project and the results of the empirical investigations from the point of view of the client company, we clearly see a direct benefit that essentially has two aspects. First, wholly irrespective of the quality of the results obtained, the company was able to consider its commissioning of a student research group as an independent social engagement activity. Specifically, it was a form of social commissioning, i.e. a targeted partnership with an organisation, whose objective in this case was the imparting of knowledge to young academics, not the maximisation of profits (cf. Dresewski, 2004, p. 21f). Incidentally, the engagement satisfied the increasing demands on companies to professionalise their 'charity practice' and 'corporate philanthropy' (cf. Kotler and Lee,
2005 , p. 24) to the extent that while it accepted the risk that the (student) contractors may not adopt a wholly professional approach, it covered itself by appointing experienced scientific specialists to mentor the students.

The second benefit achieved by Knecht \& Müller AG was a general improvement in its understanding of the development problem 'vision impairment'. In particular, it received an introduction to the most important actors and their networks and activities. This also allowed the company to obtain a picture of the 'non-actors' (some of whom were surprisingly identified as such), network gaps and fields in which the activities are inadequate or do not take place at all. In addition, the research team was able to identify, at least in general terms, the 'weaknesses' exhibited by the existing actors, networks and engagement activities.

If the investigation had been conducted in the field of business administration, it would probably have been described as the external part of a 'SWOT analysis' (Ergenzinger and Thommen, 2005, pp. 32/ 33 ). In the project under consideration, however, a conscious decision was taken not to use such a description. The use of standard marketing terms common to business practice may have simplified the discourse between social scientists and company representatives. On the other hand, however, an analysis of the market situation and market development trends was precisely what the project was not. Its aim was to shed light on a social phenomenon, which was to be signalised by the use and nonuse of certain terms.

This also implicitly addresses the issue of the goal orientation of the empirical research work and the subjection to external conditions. Throughout the project it never entered the minds of the researchers that the main purpose of their work was to solve the problem of a customer or client with a decisive influence on the process. On the contrary, each group entered the field without any preconceptions - in the best interests of the principle of openness so essential for qualitative social research (Lamnek, 2005, p. 21f). This was not just a prerequisite for results in this case study that were 'right' because they were not influenced by interventions, it is also doubtless an indispensable condition for all types of future cooperation between sociology and business. As this is the only way to counter the suspicion 
expressed in various forms that sociology is being instrumentalised by business, a suspicion that weighs both on the discipline that allows itself to be instrumentalised and on the company alleged to have made the attempt.

It is almost self-evident that this constellation entails higher communication costs. A company that can neither act as a normal client and intervene in an evaluation process as it sees fit nor knows or understands the mindset and terminology of the people it has engaged as researchers and consultants requires explanations and translations. Although these were required only to a limited extent during the project presented here due to the client's extensive knowledge, the client was nevertheless kept informed of the course of the individual projects at all times.

If we are to summarise the findings from the cooperation project under description, we can state that the role of sociology, not only in the context of CSR, but also in general, can only be 'educational' [aufklärerisch] and not 'social technological' [sozialtechnologisch], to take up two terms introduced by Ulrich Beck and Wolfgang Bonss in the title of their publication on a 1980s research programme of the German Research Foundation on Contexts of use of social science results (Beck and Bonss, 1989). We would like to emphasise, however, that does not mean that sociology should not detect, analyse and describe social problems in association with other disciplines and various organisations with the aim of deriving specific activities. Quite to the contrary, it is educational oriented sociological analysis that may substantially contribute to informed business actors, capable of coping with the social and normative frame-conditions of their business activities. The results from the project under description have made clear that sociological research generates a benefit for a company in the context of the development and implementation of a CSR strategy precisely and only if it restricts itself solely to the empirical analytical clarification of a social field or issue without pursuing its own objectives outside the scientific area.

\section{References}

Beck, U. and W. Bonss (eds.): 1989, Weder Sozialtechnologie noch Aufklärung: Analysen zur Verwendung sozialwissenschaftlichen Wissens (Suhrkamp, Frankfurt).
Becke, G.: 2003, 'Perspektiven soziologischer Beratung für eine nachhaltige Unternehmensentwicklung', in G. Linne and M. Schwarz (eds.), Handbuch nachhaltige Entwicklung: Wie ist nachhaltiges Wirtschaften machbar? (Leske+Budrich, Opladen), pp. 533-541.

Behrent, M. and J. Wieland (eds.): 2003, Corporate Citizenship und strategische Unternehmenskommunikation in der Praxis (Rainer Hampp Verlag, München/Mering).

Bollinger, H. and F. Weltz: 1989, 'Zwischen Rezeptwissen und Arbeitnehmerorientierung: Der Arbeitsbezug soziologischer Beratung von Unternehmen', in U. Beck and W. Bonss (eds.), Weder Sozialtechnologie noch Aufklärung: Analysen zur Verwendung sozialwissenschaftlichen Wissens (Suhrkamp, Frankfurt), pp. 248-275.

Bommes, M., C. Klingemann, G. Köhler and A. Scherr: 1991, 'Bereiche anwendungsorientierter soziologischer Forschung', in H. Kerber and A. Schmieder (eds.), Soziologie: Arbeitsfelder, Theorien Ausbildung. Ein Grundkurs (Reinbek bei Hamburg, Rowohlt).

Chassot Gétaz, B., K. von Däniken and T. Zeller: 2005, 'Mit der Privatwirtschaft die Millenniums-Entwicklungsziele erreichen? Beiträge von DEZA und seco', in Schweizerisches Jahrbuch für Entwicklungspolitik (edited by IUED, Geneva), pp. 61-78.

Daub, C.-H.: 2004, 'Sozialintegrative Funktionen nachhaltiger Unternehmen', in U. Mäder and C.-H. Daub (eds.), Soziale Arbeit: Beiträge zu Theorie und Praxis, pp. 153-170.

Daub, C.-H.: 2005, Globale Wirtschaft - globale Verantwortung: Die Integration multinationaler Unternehmen in den Prozess der nachhaltigen Entwicklung (edition gesowip, Basel).

Daub, C.-H. and R. Ergenzinger: 2005, 'Enabling Sustainable Management Through a New Multi-Disciplinary Concept of Customer Satisfaction', European Journal of Marketing 39(9/10), 998-1012.

Daub, C.-H., R. Ergenzinger, H. Schmassmann and M. Weik: 2003, Nachhaltigkeitsberichterstattung Schweizer Unternehmen 2002 (edition gesowip, Basel).

Daub, C.-H., Y. Karlsson, R. Ergenzinger, S. Stiller, Y. Scherrer, S. Philippi and H. Schmassmann: 2005, Geschäftsberichterstattung Schweizer Unternehmen 2005 (edition gesowip, Basel).

Dresewski, F.: 2004, Corporate Citizenship: Ein Leitfaden für das soziale Engagement mittelständischer Unternehmen (edited by Bundesinitiative 'Unternehmen: Partner der Jugend (UPJ)', Berlin).

Ergenzinger, R. and J.-P. Thommen: 2005, Marketing: Vom klassischen Marketing zu Customer Relationship Management und E-Business (Versus, Zürich).

Europäische Kommission: 2001, Europaiische Rahmenbedingungen für die soziale Verantwortung der Unternehmen (Grünbuch, Luxemburg). 
Gazdar, K., A. Habisch, K. R. Kirchhoff and S. Vaseghi (eds.): 2006, Erfolgsfaktor Verantwortung: Corporate Social Responsibility professionell managen (Springer, Berlin/ Heidelberg).

Gläser, J. and G. Laudel: 2004, Experteninterviews und qualitative Inhaltsanalyse als Instrumente rekonstruierender Untersuchungen (VS Verlag für Sozialwissenschaften, Wiesbaden).

Grayson, D. and A. Hodges: 2004, Corporate Social Opportunity: 7 Steps to Make Corporate Social Responsibility Work for Your Business (Greenleaf Publishing, Sheffield).

Habisch, A.: 2006, 'Die Corporate-Citizenship-Herausforderung: Gesellschaftliches Engagement als Managementaufgabe', in K. Gazdar, A. Habisch, K. R. Kirchhoff and S. Vaseghi (eds.), Erfolgsfaktor Verantwortung: Corporate Social Responsibility Professionell Managen (Springer, Berlin/Heidelberg), pp. 35-49.

Helfferich, C.: 2005, Die Qualität qualitativer Daten: Manual für die Durchführung Qualitativer Interviews, 2nd Edition (VS Verlag für Sozialwissenschaften, Wiesbaden).

Hillmann, K.-H.: 1988, Allgemeine Wirtschaftssoziologie: eine grundlegende Einführung (Vahlen, München).

Hirsch-Kreinsen, H.: 2005, Wirtschafts- und Industriesoziologie: Grundlagen, Fragestellungen, Themenbereiche (Juventa, Weinheim/München).

Hoering, U.: 2003, „Zauberformel PPP” - ,Entwicklungspartnerschaften" mit der Privatwirtschaft: Ausmass - Risiken - Konsequenzen (edited by Weltwirtschaft, Ökologie \& Entwicklung e.V. [Weed], Berlin/Bonn).

Hopkins, M.: 2003, The Planetary Bargain: Corporate Social Responsibility Matters (Earthscan, London).

Knecht and Müller AG: 2005, Glasklar: Zur nachhaltigen Entwicklung bei der Knecht \& Müller AG (Stein am Rhein, Switzerland).

Kotler, P. and N. Lee: 2005, Corporate Social Responsibility: Doing the Most Good for Your Company and your Cause (John Wiley, Hoboken).
Lamnek, S: 2005, Qualitative Sozialforschung: Lehrbuch, 4th Edition (Beltz, Weinheim/Basel).

Matten, D. and J. Moon: 2005, 'A Conceptual Framework for Understanding CSR', in A. Habisch J. Jonker, M. Wegner and R. Schmidpeter (eds.), Corporate Social Responsibility Across Europe (Springer, Berlin/Heidelberg), pp. 335-356.

Meuser, M. and U. Nagel: 2005, 'ExpertInneninterviews - vielfach erprobt, wenig bedacht: Ein Beitrag zur qualitativen Methodendiskussion' in A. Bogner, B. Littig and W. Menz (eds.), Das Experteninterview: Theorie, Methode, Anwendung, 2nd edition (VS Verlag für Sozialwissenschaften, Wiesbaden), pp. 71-93.

ÖBU/TSF/zsa-ZHW (eds.): 2005, Das Unternehmen in der Gesellschaft: Die soziale Dimension der Nachhaltigkeit in Theorie und Praxis - Was leisten Schweizer Unternehmen (ÖBU-Schriftenreihe Bd. 26, Zürich).

Younossian, C. S. and E. Dommen: 2005, 'Öffentlichprivate Partnerschaften: Bedeutung und Herausforderungen für die Entwicklungszusammenarbeit', in Schweizerisches Jahrbuch für Entwicklungspolitik (edited by IUED, Geneva), pp. 11-21.

Smelser, N. and R. Swedberg: 1994, 'The Sociological Perspective on the Economy', in N. Smelser R. Swedberg (eds.), The Handbook of Economic Sociology (Princeton University Press, Princeton, New York), pp. 3-23.

Claus-Heinrich Daub and Yvonne M. Scherrer School of Business, University of Applied Sciences Northwestern Switzerland, Zuercherstrasse 1202, 5210 Windisch, Switzerland E-mail: clausheinrich.daub@fhnw.ch; yvonne.scherrer@fhnw.ch 